International Journal of Engineering \& Technology, $7(4)(2018) 2718-2721$
International Journal of Engineering \& Technology
SPC
Website: www.sciencepubco.com/index.php/IJET
doi: $10.14419 /$ ijet.v7it.15678
Research paper

\title{
Certain investigations on multi input -SEPIC-RE boost-system with enhanced-response
}

\author{
B. Jagadish $\operatorname{Kumar}^{1 *}$, Dr. Basavaraja Banakara ${ }^{2}$ \\ ${ }^{1}$ Kakatiya Institute of technology \& Science, Warangal, Telangana India-506015 \\ ${ }^{2}$ Department of EEE, University UBDT Engg. College, Karnataka,India-577004 \\ *Corresponding author E-mail: jagadeesh908@gmail.com
}

\begin{abstract}
Recent developments in converters have given pathway to high-gain-step up converter having low output voltage ripple. High-gain-step up converters can be found between Photovoltaic Voltage (PV) and Direct-Current (D-C) loads. The intention of this work is to identify multi converter system for multiple input sources and to improve time response of high-gain-step up-converter. Closed-loop MultiConverter System (MCS) is utilized to regulate load voltage. This effort recommends suitable-controller for "closed-loop-controlledSEPIC-REBOOST Converter fed DC motor". The estimation of the yield in 'open-loop'\& 'closed- loop-circuit' has been done using MATLAB or Simulink. Closed-loop-control of MCS with PI and FOPID-Controllers are investigated and their responses are evaluated in conditions of rise time, peak time, settling time and steady state error. It is seen that FOPID controlled MCS gives better time domain response in terms of motor speed. A 'Prototype of MCS' has been fabricated in the laboratory\& the 'experimental-results' are authenticated with the simulation-results.
\end{abstract}

Keywords: SEPIC; Reboots Converter; FOPID Controller; Multi Input Converter

\section{Introduction}

For sustainable energy applications, a high step-up-converter with voltage-multiplier modules "was recommended by Huang. This work introduced a new-separated high stride-up-converter for sensible essential applications. Through an adjustable voltagemultiplier module, the introduced-converter achieved a high stride up get without utilizing either an expansive-obligation-proportion or a high turn's extent. The voltage-multiplier modules were made out of coupled-inductors and exchanged-capacitors. On account of the idle lossless fastened execution, spillage imperativeness was reused, which facilitated a gigantic voltage spike over the essential switches and upgrades capability [1].

Because of the indistinguishable course of action resistor of the boost-inductor, customary boost-converters were not prepared to surrender high voltage pick. A high-profitability high-stride up converter was proposed, with little voltage burden on control switch, control diodes and yield capacitors. The boost-converter filled in as a dynamic-brace-circuit to smother the voltage-spike on control turn in the midst of the kill-transient period. The key variables for sustainable-energy-power-conversion in modern applications were Efficiency, control quality, and unwavering quality. Du introduced a new plan to enhance exhibitions of highvoltage expansive limit photovoltaic power stations. Tseng [2] gave 'Novel high-proficiency step-up converter'. Liang [3] displayed 'Examination of incorporated lift fly-back step-up converter'. The working models, theoretical examination, and diagram arrangement of a high-capability wander up converter were shown. The coordinated boost fly-back converter (IBFC) used coupledinductor methodologies to achieve high-stride-up voltage with low commitment extent, and thusly the inclination-pay-circuit was discarded. "Renewable-energy-systems with photovoltaic-power- generators, operation and-modeling" was recommended byBialasiewicz. A generous increment of photovoltaic (PV) powergenerators establishments has occurred as of late, because of the expanding proficiency of sun oriented cells and in addition the enhancements of assembling innovation of sun oriented boards.

These generators are both grid-associated and remain solitary applications [4]. A hybrid fuel cell power system was proposed \&it comprises of a 'fuel-cell, an isolated-unidirectional-converter, a bi-directional-converter, an-inverter and a-battery'. A new unidirectional-converter, hybrid- full - bridge-LLC-resonant converter, was proposed and goes about as a unidirectional-converter in the system[5]. Plan and analysis of a grid-associated photovoltaic power-system was given by Zhao[6]. An elevated effectiveness high step-up converter with little switch-voltage-stress for 'fuel cell' system-applications was exhibited by Pan[7]. The voltagespike that happens on the power- switch is eased permitting a lowvoltage-appraised power-switch with low RDS (ON) and in this way decreases the conduction-misfortunes were exhibited by-KuoChing Tseng. This examination displays a novel DC-DCconverter for renewable-energy-conversion-systems with photovoltaic (P V) sun based cell or fuel-cell-stack input. The proposed converter was depended on a boost-converter and a voltagedoublers setup with a coupled inductor to accomplish high advance up voltage change ratio [8].

The exceeding-writing do not deal with input-combination of 'SEPIC and RE-BOOST converters'. These effort suggests a combination of 'SEPIC and RE-BOOST-converters' to enhance power-output. The exceeding-writing does not deal with 'comparison of responses of PI \&FOPID-controlled MCS-system'. This effort proposes FOPID for the control of 'SEPIC\&REBOOSTsystem'. 


\section{System-description}

The 'Block-Diagram of Closed-Loop-MCS with PI-Controller' is exposed in Fig-1.1. 'Actual-speed' is evaluated with the 'reference-speed' and the error is applied to PI. The 'output of PI' is given to a comparator which evaluates 'saw-tooth' with the 'output of PI'. The MCS-system updates the width of pulse-applied to the MOSFET of SEPIC \&RBC.

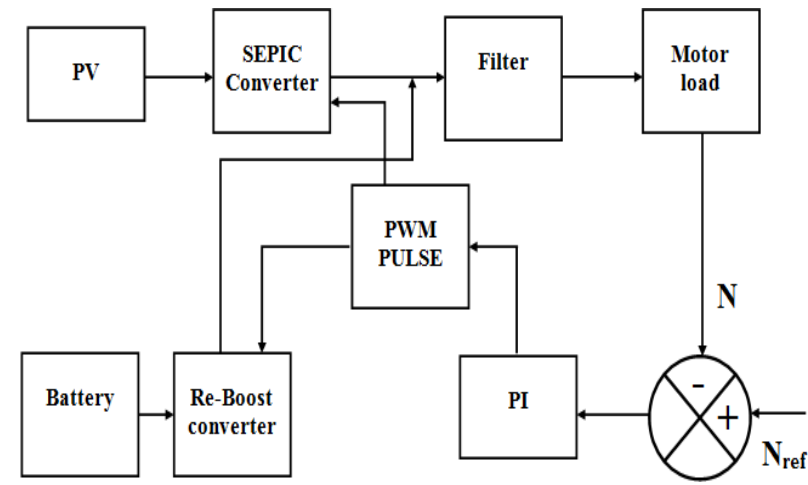

Fig. 1.1: 'Block-Diagram of Closed-Loop-MCS with PI-Controller'.

The Block-Diagram of Closed-Loop-MCS with FOPID-Controller is exposed in Fig-1.2. 'Actual-speed' is evaluated with the 'reference-speed' and the 'error is applied' to FOPID. The 'output of FOPID' is given to a comparator which evaluates saw-tooth with the 'output of FOPID'. The FOPID system updates the 'width of pulse' applied to the MOSFET of SEPIC\& RBC.

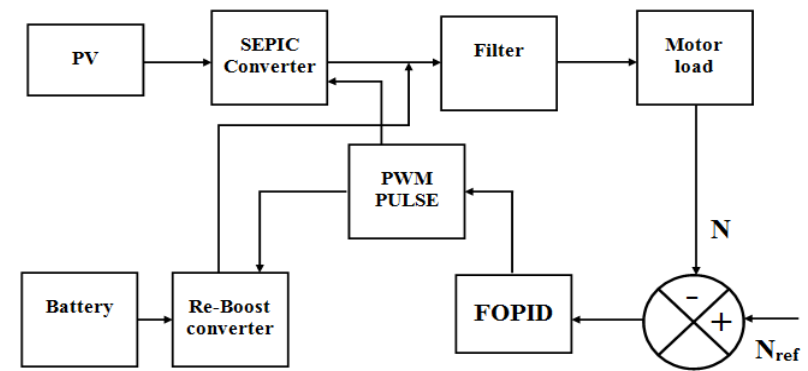

Fig. 1.2: 'Block-Diagram of Closed-Loop-MCS with FOPID-Controller'.

\subsection{Analysis}

Equivalent ' $\mathrm{L}$ and $\mathrm{C}$ ' are expressed as follows:

$\mathrm{L}=\frac{\mathrm{V}_{\mathrm{i}} \mathrm{D}}{\mathrm{f} \Delta \mathrm{I}}$

$\mathrm{C}=\frac{\mathrm{D}}{2 \mathrm{fsR}}$

'Output of PID' is as follows:

$\mathrm{V}_{\mathrm{O}}=\mathrm{K}_{1} \mathrm{e}+\mathrm{K}_{2} \int \mathrm{e} \mathrm{dt}+\mathrm{K}_{3} \mathrm{de} / \mathrm{dt}$

$\mathrm{K}_{1}$ '`Proportional-error-constant'

$\mathrm{K}_{2}$ '“Integral-error-constant'

$\mathrm{K}_{3-}$ 'Derivative-error-constant'

'Efficiency' is calculated as follows:

$\eta=\mathrm{V}_{2} \mathrm{I}_{2} / \mathrm{V}_{1} \mathrm{I}_{1}$

$\mathrm{V}_{1 \text { - 'Input }}$-Voltage'

$\mathrm{V}_{2}$ ' 'Output-Voltage'

$\mathrm{I}_{1}$ - 'Input-Current'

$\mathrm{I}_{2}$-'Output-current'

\section{Simulation results}

Multi level inverter system with multiple input sources of closedloop-system with PI-controller is appeared in Fig-2.1. The inputvoltage of MLIS-MIS is appeared in Fig-2.2\& its value $14 \mathrm{~V}$. The Motor-speed of MLIS-MIS is appeared in Fig-2.3\&its value is 600RPM. The Torque-Response of MLIS-MIS is appeared in Fig$2.4 \&$ its value is $0.9 \mathrm{~N}-\mathrm{m}$.

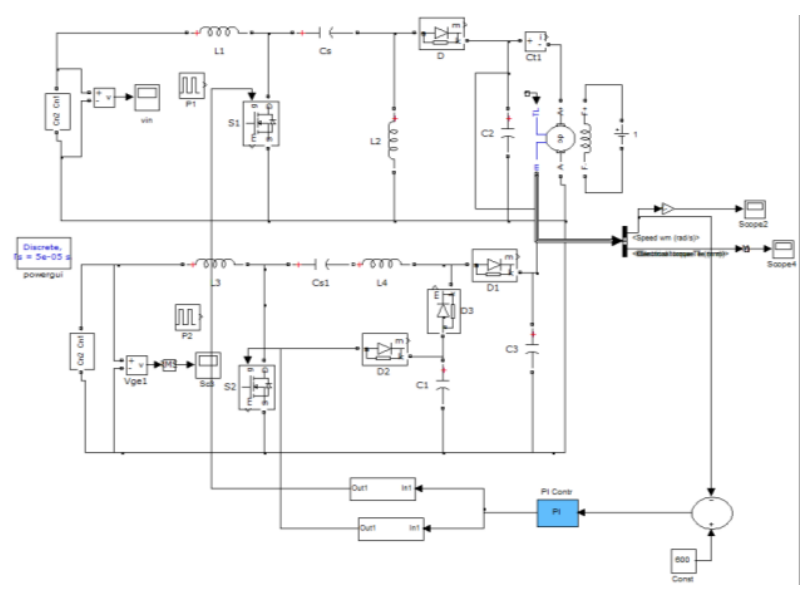

Fig. 2.1: Closed-Loop-MCS with PI-Controller.
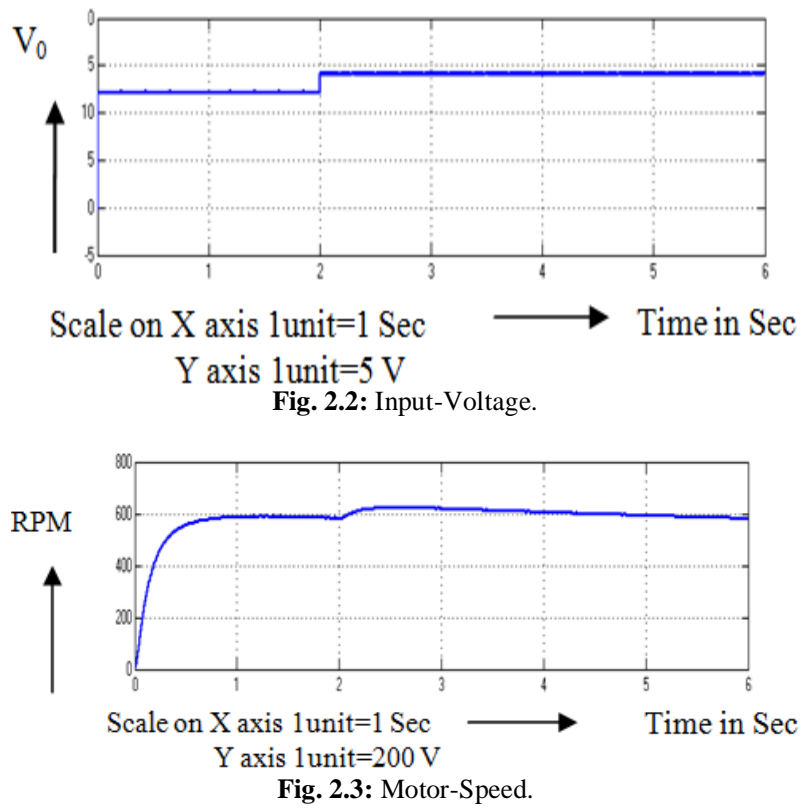

$\mathrm{N}-\mathrm{m}$

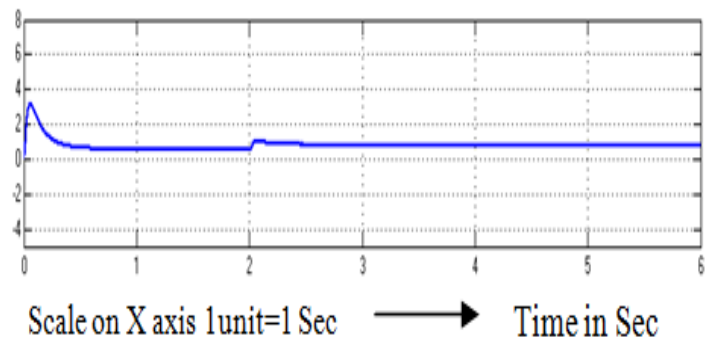

Y axis lunit $=2 \mathrm{~V}$

Fig. 2.4:. Torque

'Closed-loop-MCS with FOPID-Controller' is appeared in Fig-3.1. The Motor-speed of MLIS-MIS is appeared in Fig-3.2 \&its value is 550 RPM. The Torque-Response of MLIS-MIS is appeared in Fig-3. \& its value is $1 \mathrm{~N}-\mathrm{m}$. 


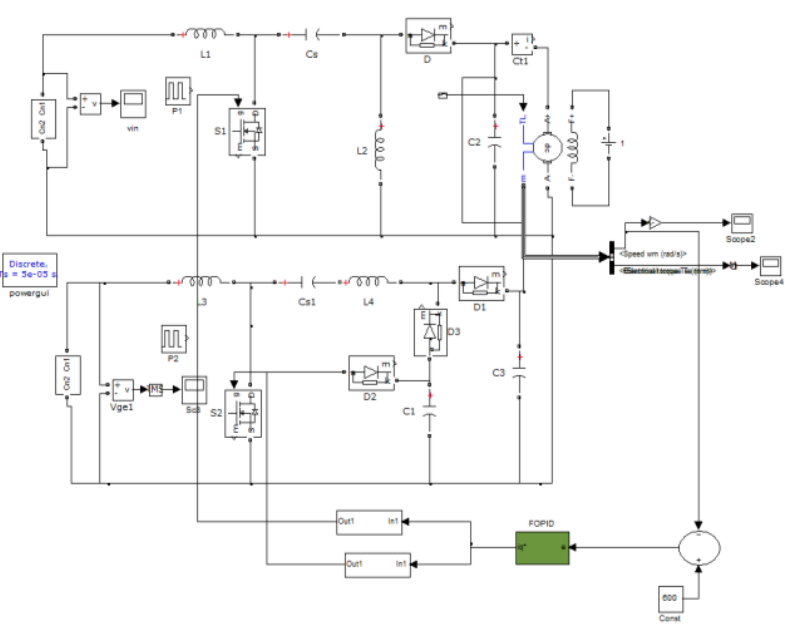

Fig. 3.1: Closed-Loop-MCS with FOPID-Controller.

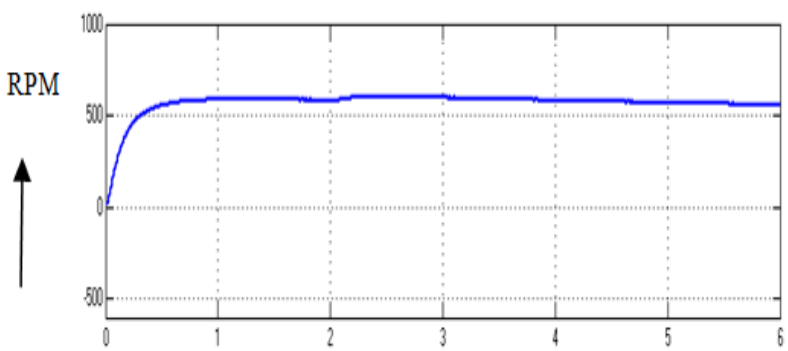

Scale on $\mathrm{X}$ axis lunit $=1 \mathrm{Sec} \longrightarrow$ Time in Sec $\mathrm{Y}$ axis lunit $=500 \mathrm{~V}$

Fig. 3.2: Motor-Speed.

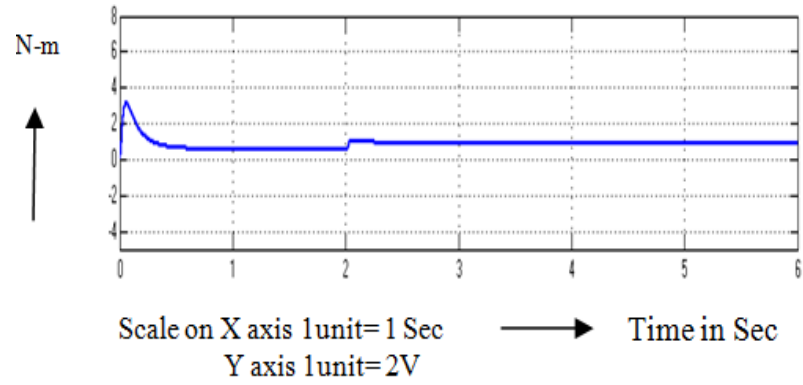

Fig. 3.3: Torque

The 'evaluation of Time-domain-parameters' (Vref=600rpm) is given in Table-3. By using-FOPID-controller, the'settling-time' is decreased from 3.8 to $3.0 \mathrm{sec}$; the 'steady-state-error' in speed is decreased from 2.2 to $1.4 \mathrm{Rpm}$; the rise-time is reduced from 2.3 sec to $2.2 \mathrm{sec}$; the peak-time is reduced from 2.8 to 2.5 seconds Therefore the response with FOPID-controller is better-than-that of PI- controlled-MLIS-MIS -system.

Table 1:.Evaluation of Time-Domain-Parameters (Vref=600rpm)

\begin{tabular}{lllll}
\hline Controller & $\mathrm{T}_{\mathrm{r}}(\mathrm{sec})$ & $\mathrm{T}_{\mathrm{s}}(\mathrm{sec})$ & $\mathrm{T}_{\mathrm{p}}(\mathrm{sec})$ & $\mathrm{E}_{\mathrm{ss}}(\mathrm{rpm})$ \\
\hline PI & 2.3 & 3.8 & 2.8 & 2.2 \\
FOPID & 2.2 & 3.0 & 2.5 & 1.4 \\
\hline
\end{tabular}

\section{Hardware results}

Multi level inverter system with multiple input sources for hardware-snap shot is exposed in Fig-4.1. The Output-voltage of solar is appeared in Fig-4.2. The Output-voltage of battery is revealed in Fig-4.3. The switching-pulse for Sepic\& re-boost converters (M1,M2) is appeared in Fig-4.4. The output-voltage of Sepic\& re-boost converter is revealed in Fig-4.5.

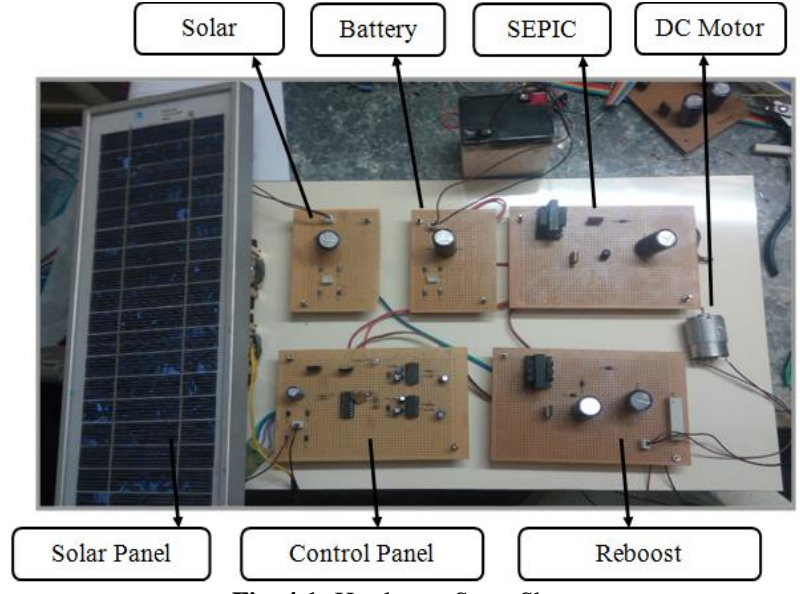

Fig. 4.1: Hardware-Snap-Shot

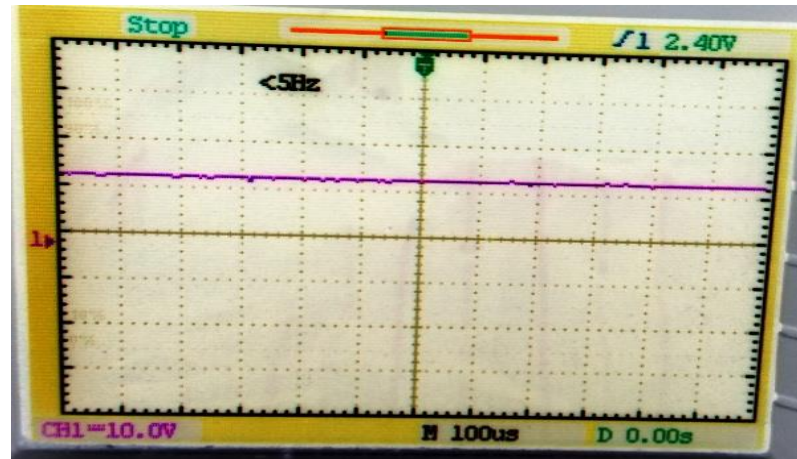

Fig. 4.2: Output-Voltage of Solar.

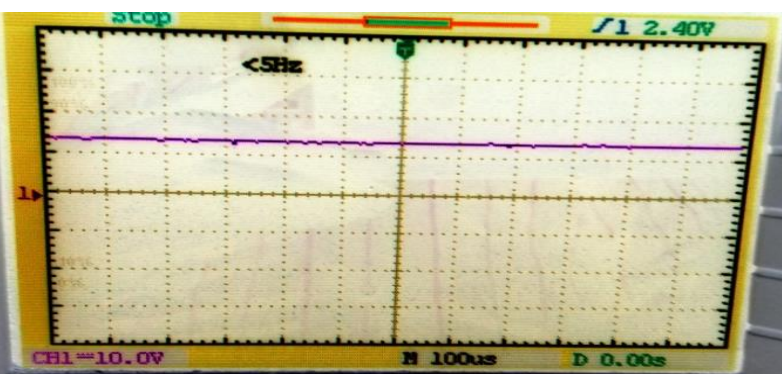

Fig. 4.3: Output-Voltage of Battery.

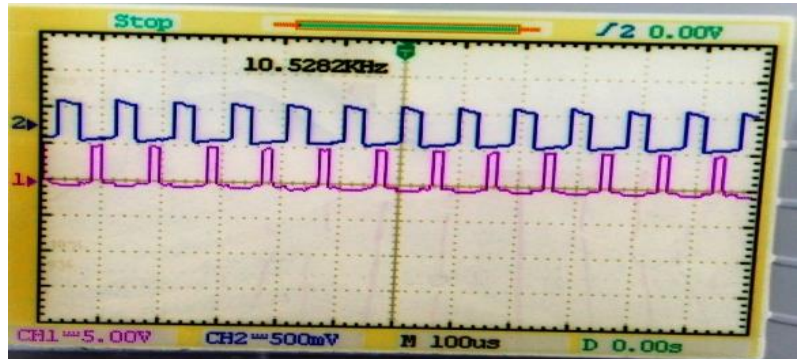

Fig. 4.4: Switching-Pulse for 'Sepic\& Re-Boost-Converters'.

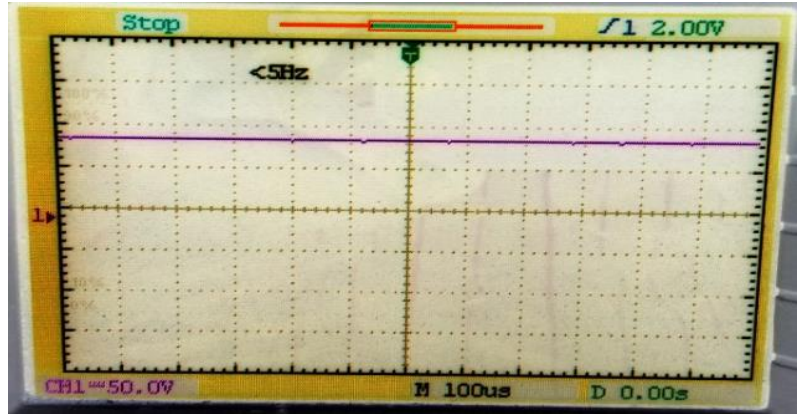

Fig. 4.5: Output-Voltage of Re-boost-Converter. 


\section{Conclusion}

The performance comparison of boost-converter and re-boostconverter is done in simulation using Simulink. Simulation-results are compared in terms of output-voltage. The results ensure that Modified-Re-boost-converter produce better performance compared to the boost-converter. 'Prototype of MCS-system' is constructed \&tested. The experimental-results are validated with simulation-results. Closed-loop-controlled-MCS for DC-motor with PI and FOPID-controller is modeled and simulated. The 'simulation-results' indicated that the settling-time is as low as $3 \mathrm{sec}$ using FOPID. The 'steady-state-error' in speed isl.4 RPMusing FOPID. Therefore FOPID- controlled-MCS-fed DC-motor has better dynamic-response. The present-work deals with Closedloop-controlled-MCS with PI and FOPID-controllers. The evaluation of responses with 'PI and PR' will be done in future.

\section{References}

[1] K. C. Tseng, -C. C. Huang and -C. A. Cheng, "-A-high-step-upconverter with-voltage-multiplier modules- for-sustainable-energyapplications," -IEEE-J-Emerg. -Sel. -Topics -Power-Electron. To be -published, https://doi.org/10.1109/JESTPE.2015.2404943

[2] K. C. Tseng and -T. J. Liang, "-Novel-high-efficiency-step-upconverter," -Inst. -Elect. -Eng. -Proc.-Electr. -Power-Appl., vol-151, no 2, pp-182-190, Mar-2004.

[3] T. J. Liang and -K. C. Tseng, "-Analysis of-integrated-boost-flyback-step-up-converter," -Inst. -Elect. Eng. - Proc.-Electr. PowerAppl., vol-152, no.-2, pp-217-225, Mar- 2005.

[4] J. T. Bialasiewicz, "-Renewable-energy-systems with-photovoltaicpower-generators: -Operation and -modeling,"- IEEE-Trans. -Ind.Electron. vol- 55, no- 7, pp- 2752-2758, Jul-2008.

[5] K. Jin, -X. Ruan,- M. Yang, and -M. Xu, "-A-hybrid-fuel-cellpower-system,” -IEEE -Trans. -Ind. -Electron., vol-56, no- 4, pp1212-1222, Apr-2009.

[6] B. Yang, -W. Li, Y. Zhao, and -X. He, "-Design and-analysis of agrid-connected-photovoltaic-power -system," -IEEE -Trans. -Power Electron., vol-25, no 4, pp-992-1000, Apr-2010.

[7] C.-T. Pan and -C.-M. Lai, “-A high-efficiency-high-step-upconverter with low-switch-voltage-stress for-fuel-cell-systemapplications," -IEEE -Trans. -Ind. -Electron. Vol-57, no 6, pp1998-2006, Jun- 2010

[8] S.-K. Changchien,-T.-J. Liang, J.-F. Chen, and -L.-S. Yang, “Novel-high-step-up DC-DC-converter for-fuel-cell-energyconversion-system," -IEEE-Trans. Ind.-Electron., vol- 57, no- 6, pp- 2007-2017, Jun- 2010.

[9] H. Ghoddami and -A. Yazdani, “-A single-stage-three-phasephotovoltaic-system with enhanced- maximum-power-pointtracking-capability and- increased-power-rating,"- IEEE-Trans. Power-Del., vol-26, no- 2, pp-1017-1029, Apr-2011. 